\title{
Water Pollution, Fish Migration and the Plight of Fish Famers: A Biblical-Contextual Analysis
}

\author{
Ucheawaji G. Josiah, Ph.D \\ Lecturer of Old Testament Studies/African Ecological Hermeneutics in Religious Studies Department, Babcock \\ University, Ilishan-Remo, Ogun State, Nigeria \\ Dr. Evans N. Nwaomah \\ Lecturer in Family studies in Religious Studies Department, Babcock University, Ilishan-Remo, Ogun State, \\ Nigeria
}

\begin{abstract}
The relationship between unethical activities in the water zones and fish migration in ancient Israel and contemporary Rivers State (R/S) cannot be overemphasized. This study focused on the linkage between unethical activities and fish migration in ancient Israel and especially, contemporary R/S of Nigeria. This work utilised the Historical-Grammatical method for analysis of Biblical text of Hosea 4:3c and survey method for gathering of data from 583 respondents in R/S. The data collated were subjected to Simple Percentage Ratings and Content analyses. Accordingly, findings revealed that in Hosea 4:1-2, dysfunctional community relationships ( $w^{e}$ 'en-chesed) manifested in destructive activities (pārats), while Hosea 4:3c echoed the attendant consequences as fish migration owing to excessive fishing motivated by greed. Similarly, in Rivers State, the unethical use of chemical and explosive as fishing gear was attested to by $89.4 \%$ of the Residents. Equally, a whopping $84.9 \%$ of the respondents believed that there was a reduction in the amount of fish brought home from fishing activities due to recent use of chemicals and explosives as part of fishing strategies. Residents from fresh water zone applied gammalin20 while those of saline water zone used dynamite as fishing techniques. This resulted in non-selective mortal damage, which left water sources stinking after two days. Thus, was detrimental to the economic life of families that depended on fishing for livelihood. Therefore, the role of residents and the government remains imperative for the environmental remediation in Rivers State as this will ameliorate the economic downturn of fish farmers.

Keywords: gammalin20/dynamite, fishing strategies, fish migration, coastal rivers state, family livelihood, hosea $4: 3 \mathrm{c}$

DOI: $10.7176 / \mathrm{JEES} / 9-9-04$

Publication date:September $30^{\text {th }} 2019$

\section{Introduction}

There appears to be a significant nexus between unsafe ecological zone and fish migration in Hosea 4:3c and this by extension could impact on families that depend on fishing for livelihood. In Hosea 4:1, YHWH indicts Israel for the lack of attributes, such as, אֶֶֶ 'emeth - reliability, -chesed - functional community relationship, though these qualities can be interpreted either morally or religiously (Sakenfeld, 1978). Unfortunately, in verse 2, YHWH is portrayed as accusing ancient Israel of breaching the known contents of the Torah (Hayes, 2002). Within this same verse, YHWH is pictured as recounting the people's misdeeds against one another as portrayed in the use of five infinitive absolute verbs: 'They were always cursing, lying, killing, stealing, and committing adultery' (Hosea 4:2). However, most commentators note, that the above five infinitive absolutes are more than a list of social evils (Mays, 1969). The last three of those verbs are categorically forbidden by the moral law, that is, the

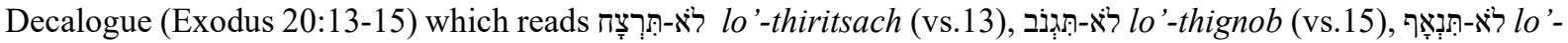
thina 'af (vs.14) literally meaning: "do not kill” (vs. 13), "do not steal or kidnap" (vs. 15)," "do not commit adultery" (vs. 14). Moreover, the first infinitive, אָל 'aloh used by Hosea in 4:2 denotes the ceremonial use of Yahweh's name in cursing someone and is therefore a violation of the Torah in Exodus 20:7 (Mays, 1969). The Prophet's second accusation, וְכָ -lying is explicitly banned in only one Old Testament law especially, in Leviticus 19:11:

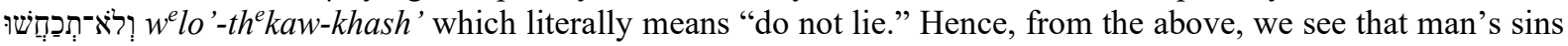
against his neighbours are looked upon also, as a violation of YHWH's stipulations. Therefore, Israel's breaking of the Torah manifests itself in two ways: wrong attitudes to YHWH, and wrong actions against one another as well as against the environment - vertical and horizontal relationships.

As a result of such breach on those stipulations, YHWH in vs. 3 is alleged of pronouncing "judgment" upon

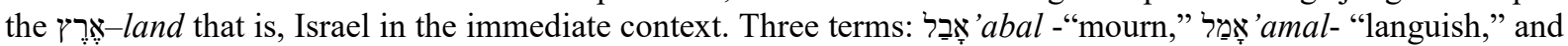
ఇָพ 'asof- "migration" are used to depict the lamenting condition of land and population (Mays, 1969) in the land, air and water habitats, which the Prophet identifies as: the languishing of everyone that dwells therein, with the "beasts of the field" (land), while the "birds of the sky" and the fish of the sea" are being "taken away" (air and water) (Hosea 4:3). Therefore, it could be asserted that the book of Hosea 4:1-3, presents a devastating, and chaotic condition of the ancient Israel's environment with an assumption that there is a link between unethical conduct in
\end{abstract}


ancient Israelite society, and chaos in the environment. The environment, in this regard according to Dewitt (1991) includes human, animals, birds, fish and other non-human elements. Accordingly, Wittenberg observed that there is a broad unity between cosmic, political, and social order in the ancient Near Eastern concept of creation. Therefore, disorder in the social realm remains detrimental to the cosmic realm (Wittenberg, 2009). Given this backdrop, this study however, analyzes the economic situation of fish farmers in Rivers State with the aim to achieving economic stability.

\section{Methodology}

A qualitative and quantitative design was adopted for this study. First, the Historical-Grammatical Method (Terry, 1976) was utilised as exegetical platform to interpret the purposively selected text of Hosea 4:3. This exegetical model is premised on the stance that no event or text can be understood unless it is seen in terms of its historical and grammatical context. It also approaches the text in its final form and at face value, with no recourse to textual evolution.

Nevertheless, structured questionnaire was administered to generate information regarding the interrelatedness between unethical conduct and ecological damage especially as it relates to fish fetching and the economic status of the fish farmers. The sample size has been calculated from the total population of six (6) Local Government Areas (LGAs) across the three (3) senatorial districts of Rivers State. They are: Rivers East (Andoni and Khana LGAs), Rivers Central (Etche and Port Harcourt LGAs) and Rivers West (Ogba-Egbema-Ndoni and Ahoada East LGAs) Senatorial districts. According to the 2006 population census (NBS, 2007) in Nigeria, the populations of these local government areas are as follows: Ahoada-East (166,747), Andoni $(211,009)$, Etche $(249,454)$, Khana $(294,217)$, Ogba-Egbema-Ndoni $(284,010)$, and Port-Harcourt $(541,115)$. These individual populations sum up to $1,746,552$ people living in these Local Government Areas.

The formula applied in calculating the sample size is Gonzalez' (2008) sample size formula: $\mathrm{n}=\mathrm{N} / 1+\left[\mathrm{N}\left(\mathrm{e}^{2}\right)\right]$, where $\mathrm{n}=$ sample size, $\mathrm{N}=$ total population of the understudied universe, and $\mathrm{e}=$ percentage margin of error at 4 percent error margin (which implies 96 percent accuracy), the total population size $(\mathrm{N}=1,746,552)$ produced a sample population of $n=624$; Making the sample population size for this study as 624 respondents. Out of the $624(100 \%)$ copies of the questionnaire administered to study sample representing the opinions of Rivers State residents, $583(93.4 \%)$ opinions were generated for analysis. In the course of analyzing the data collated, Simple Percentage Rating was used to analyze the data collated, leading to the estimations and conclusions reached in this study. Descriptive and inferential statistical tools such as tables and averages were adapted for needed data analyses.

\section{Theoretical Framework}

Thomas Aquinas' theory of natural law (Lisaka, 1996) which succinctly asserts that right participation in the eternal law (that is, the rational plan by which all creation is ordered) results in goodwill while any deviation from this order causes disaster and not necessarily a curse from God. He further posits that the natural law is given by God and it is naturally knowable by human beings and that right actions are actions that correspond non-defectively to the good. Again, He held that the fundamental good is self-preservation (Murphy, 2011).

\section{Literature Review}

The concept of Eco-justice according to Nwaomah (2013) could be traced to the concern of a group of North American, ecumenically-engaged Christian ethicists who in the 1970s after the first Earth Day were burdened with the lack of adequate principles of social ethics to address the environmental challenges of society. A strategy to integrate ethics of ecology and justice became the focus of an ecumenical campus ministry initiative at Cornell University called the Eco-Justice Project and Network (EJPN) by 1970. To this team of Christians, Eco-justice is the well-being of humankind on a thriving earth; The wellbeing of an earth productive of sufficient food, with water fit for all to drink, air fit to breathe, forests kept replenished, renewable resources continuously renewed, nonrenewable resources used as sparingly as possible so that they will be available for future generations (Bullard, nd.)

Interestingly, though the Hebrew scriptures of Judaism do not provide for an objective environment set apart from human beings it does recognise that humans too are part of the environment (DeWitt. 1991). It therefore follows that any attempt to destabilize the environment, is an attempt to destabilize the humans as well. It is thus the attempt to maintain an ecological balance that this work explores the ecological consequences of unethical conduct on Water and its resultant effect in Fish Migration which further hampers on man's survival.

Similarly, Robert D. Bullard opines that "Eco-justice is the fair treatment and meaningful involvement of all people regardless of race, color, nationality, or income with respect to the development, implementation, and enforcement of environmental laws, regulations, and policies (Bullard, nd). This implies that all humans including non human elements in the sea (fish) as well are entitled to equal protection. These concerns thus lead to social responsibility and ethical considerations in the use of the environment. Clearly put, eco-justice, calls for decisionmaking that incorporate social, economic, cultural and environmental concerns and issues in the quest for 
humankind to appropriate to itself the abundant resources that nature provides.

Addressing the link between morality and environmental wellbeing, Berry (et.al) (2005) see Israel's land as microcosm of the earth; and God being the divine landlord makes Israel whole economic system subject to moral critique. They state a major concern of the Old Testament law to be "justice in the use and distribution of the products of economic activity" they postulate that the Old Testament law's seems to redress the economic balance by structural measures aimed especially at the control of debt (Exodus 22:25, Lev 25: 36, Deut. 23:19, 24:6-10) and other factors to relieve poverty and to restore the poor to dignified participation in the community gleaning rights (Lev. 19:9 Deut. 24: 19 - 22), etc. the author holds that all of this was part of the structures of Israel's economic system, to encourage justices and compassion in the ordinary vicissitudes of a functioning economy.

Because the land functioned like a moral and spiritual barometer in the Old Testament, much of the prophetic anger is directed at economic injustice (an offshoot of social injustice) and oppression in which the abuse and misuse of the land is dominant. They hold that the combination of idolatry and injustices is still much in evidence in our own world (Berry, et.al, 2005). It is in light of the foregoing statement, that this literature is relevant to this research. Again, the relationship between social injustices as stated in Hosea 4:1-3 and the wellbeing of the Hebrew land remains highly important for fish farmers in the Niger Delta region of Nigeria. There are incidences of oilmineral pollution within the Niger Delta region of Nigeria that are not receiving equivalent environmentally remedial attention. Such negligence or oversight (as the case may be) further heightens the degree of ambient ecological deterioration in the Niger Delta. We see that evident in the findings of from an experimental work done by Josiah and Amah (2013) that the region is highly predisposed to pollution assault occasioned by hydrocarbon (oil-mineral and related products). It shows that the different parts of the region is exposed to the pollutant at differing magnitudes as some are much more susceptible than the others (Josiah \& Amah 2013). The effect of this pollutant is revealed in the level of fish migration in the region as this has affected the fish farmers in those regions negatively.

\section{Economic Value of Fish amongst the Jews}

Reflecting on the wilderness experience, during the exodus, it is germane to highlight the complaint by the Israelites: "We remember the fish we used to eat in Egypt" (Num 11:5). This complaint summarizes the economic as well as dietary importance of fish to this group of ancient Israel. Nevertheless, fish provided an important source of protein for the ancient Israelites. Fish were largely used as food (Hab. 1:16), hence, the lamentation of the fishermen, who provided for all, typified general desolation (Isa 19:8). On the other hand, abundance of fish and many fishermen indicated general abundance (Ezek 47:10) (Patch, n.d). Fish, the Hebrews dag, is a word denoting great productiveness (Gen 9:2; $\mathrm{Nu}$ 11:22; Jon 2:1, 10). Fish abounded in the Mediterranean and in the lakes of the Jordan, so that the Hebrews were no doubt acquainted with many species. At least, two of the villages on the shores of the Sea of Galilee even derived their names from their fisheries: Bethsaida (the "house of fish") on the east and on the west. In fact, there was a regular fish-market apparently in Jerusalem (2 Ch 33:14; Ne 3:3; 12:39; Zep 1:10) (Lernau and Larnau, 1992) and also a fish-gate which was probably adjoining to the market where fish were supplied chiefly through Tyrian traders who imported it (Neh. 13:16; 3:3; 12:39; 2 Chr. 33:14) (Patch, n.d).

In the course of fishing, the net was used among the Hebrews as fishing gear. The fishing-net was probably constructed after the form of that used by the Egyptians (Isa 19:8). There were three kinds of nets in use then. They were: (1.) A long net or seine (Gr. sagene), of one or two fathoms depth, with lead on one edge and provided with floats on the other, was laid out from boats in such a way as to surround a school of fish. Long ropes fastened to the two ends were carried ashore many yards apart, and from five to ten men on each rope gradually draw in the net. The fish were then landed from the shallow water with small nets or by hand. This method was commonly practiced by ancient Israelites (Mt 13:47, 48) (Thomas, 2006). (2.) The hand-net or casting-net (Gr. amphiblestron), which was thrown from a rock or a boat at any fish that might be seen (Mt 4:18; Mr 1:16). It was of circular form, like the "top of a tent." (3.) The bag-net (Gr. diktyon), used for enclosing fish in deep water (Lu 5:4-9) (Easton, n.d).

Indeed, fishing was an important industry in Western Palestine (Day, n.d). Because fish provided an important source of protein for the ancient Israelites, and were largely used as food (Hab 1:16), and as well provided a source of livelihood for them (2 Ch 33:14; Ne 3:3; 12:39; Zep 1:10), (Lernau and Larnau, 1992) the increase need for more profit, led to the excessive fishing motivated by greed which ended up in the reduction of the catch. This is what Feinberg intended when he said that severe environmental damage is often the result of the accumulation of individually negligible effects (Feinberg, 1984). Moreover, Gibson, a leading proponent of eco-justice, asserts that it is expected of mankind to maintain a thriving earth productive of sufficient food, with water fit for all to drink, air fit to breathe, forests kept replenished, renewable resources (like fish) continuously renewed, non renewable resources used sparingly as possible so it could be reserved for future generations. But this was not the case. Hence, Schmid quoted in Wittenberg (2009), sees a broad unity between cosmic, political, and socio-economic order in the ancient Near Eastern concept of creation. 
Commensurately, Hayes (2002) holds that the consequences in Hosea 4:3 are direct results of the unethical deeds done on the land by the ancient Israelites. Therefore rather than accepting that the fateful consequences in nature are due to an active punishment by Yahweh, it rather follows that "Yahweh merely watches over the organic connection between human deed and the fateful consequences that follow organically out of it" (Wittenberg, 2009). Given the foregoing position, it therefore suggests that unethical conduct in a given society does not only affect adversely, the society but nature as well.

Unethical Conduct and Environmental Degradation in Rivers State Background of the Respondents (Community Residents) Respondents' Profile

Table 1: Demographic information (Rivers Residents)

\begin{tabular}{|c|c|c|c|}
\hline \multicolumn{2}{|c|}{ Demographic characteristics } & \multirow{2}{*}{$\begin{array}{c}\text { Frequency } \\
62\end{array}$} & \multirow{2}{*}{$\begin{array}{c}\begin{array}{c}\text { Percentage } \\
\%\end{array} \\
10.6\end{array}$} \\
\hline L.G.A & Ahoada East & & \\
\hline & Andoni & 76 & 13.0 \\
\hline & Etche & 82 & 14.1 \\
\hline & Khana & 106 & 18.2 \\
\hline & Ogba/Egbema/Ndoni & 95 & 16.3 \\
\hline & Port-Harcourt & 162 & 27.8 \\
\hline & Total & 583 & 100.0 \\
\hline \multirow[t]{5}{*}{$\begin{array}{l}\text { No. of years of } \\
\text { Residence }\end{array}$} & $5-9$ & 79 & 13.6 \\
\hline & $10-14$ & 48 & 8.2 \\
\hline & $15-19$ & 119 & 20.4 \\
\hline & 20 and above & 335 & 57.5 \\
\hline & Total & 581 & 99.7 \\
\hline \multirow[t]{5}{*}{ Religion } & Christianity & 549 & 94.2 \\
\hline & Islam & 15 & 2.6 \\
\hline & $\begin{array}{l}\text { African Indigenous } \\
\text { Religion }\end{array}$ & 13 & 2.2 \\
\hline & Others & 6 & 1.0 \\
\hline & Total & 583 & 100.0 \\
\hline \multirow[t]{6}{*}{ Age Profile } & $15-24$ & 129 & 22.1 \\
\hline & $25-34$ & 174 & 29.8 \\
\hline & $35-44$ & 115 & 19.7 \\
\hline & $45-54$ & 91 & 15.6 \\
\hline & 55-above & 74 & 12.7 \\
\hline & Total & 583 & 100.0 \\
\hline
\end{tabular}

Rivers state is one comprising of 23 local government areas (LGAs) subdivided into three (3) senatorial districts: Rivers East, west, and central. But in this work, Ahoada-east and Ogba-Egbema-Ndoni L.G.As fall within Rivers West; Khana and Andoni, within Rivers East while Etche and Port-Harcourt L.G.As are located in Rivers central senatorial district. Within these senatorial districts, the sample profile and coverage of the respondents reveal the different backgrounds of respondents taking into cognizant the Local Government Area where 62 (10.6\%) were from Ahoada East; 76 (13\%) Andoni; 82 (14.1\%) Etche; 100 (18.2\%) Khana; 95 (16.3\%) Ogba/Egbema/Ndoni; and 162 (27.8\%) Port-Harcourt. Out of these 583 respondents, majority numbering about $335(57.5 \%)$ had lived over 20 years in their present location while $119(20.4 \%), 48(8.2 \%)$ and79 (13.6\%) had stayed in their location for 15-19 years, 10-14 and 5-9 years respectively.

The religious affiliation of the people is not surprising because the people of Rivers State are predominantly Christians. This is evident in their responses of which $94.2 \%$ are Christian while $2.6 \%, 2.2 \%$ and $1 \%$ are Muslim, African indigenous religion observers and others respectively. Majority of the respondents (29.8\%) falls between the age categories of 25-34 years, $22.1 \%$ are $15-24$ years of age, $19.7 \%$ are of $35-44$ years of age, $15.6 \%$ are $45-$ 54 years of age and $12.7 \%$ are of 55 years and above. 
Effect of Unethical Deed on Land, air and water in Rivers State

Table 2: Test on Respondents' affirmation on evidence of land, air and water Degradation Resulting from Unethical Deed

\begin{tabular}{|l|l|l|l|l|l|}
\hline S/N & \multicolumn{1}{|c|}{ ITEMS } & $\begin{array}{l}\text { Agree } \\
(\%)\end{array}$ & $\begin{array}{l}\text { Undecided } \\
(\%)\end{array}$ & $\begin{array}{l}\text { Disagree } \\
(\%)\end{array}$ & Total \\
\hline 1 & $\begin{array}{l}\text { Humans, animals, fish and trees are becoming healthier } \\
\text { these days than some 20 years ago in spite of harmful } \\
\text { activities and pollution in my community }\end{array}$ & $\begin{array}{l}57 \\
(9.8)\end{array}$ & $\begin{array}{l}36 \\
(6.2)\end{array}$ & $\begin{array}{l}490 \\
(84.0)\end{array}$ & $\begin{array}{l}583 \\
(100)\end{array}$ \\
\hline
\end{tabular}

The situation of air pollution in the test item above, could also inform the $84 \%$ (490) respondents who disagreed with the statement, that human beings, animals and trees are becoming healthier these days than some 20 years ago while a few respondents $9.8 \%$ agreed to the statement. According to Watts, life expectancy in the Rivers State (Niger Delta) region has actually fallen in recent decades because environmental degradation has undermined community livelihoods. Beyond the pollution of local farmland and water supplies, the extraction and processing of oil have also had serious environmental consequences at a global level (Watts, 2007).

Table 3: Test on Respondents' affirmation on evidence of fish reduction due to the People's use of chemicals, explosives and vandalism

\begin{tabular}{|l|l|l|l|l|l|}
\hline S/N & \multicolumn{1}{|c|}{ ITEMS } & $\begin{array}{l}\text { Agree } \\
(\%)\end{array}$ & $\begin{array}{l}\text { Undecided } \\
(\%)\end{array}$ & $\begin{array}{l}\text { Disagree } \\
(\%)\end{array}$ & Total \\
\hline 1 & $\begin{array}{l}\text { The amount of fish brought home from fishing outing in } \\
\text { our river is plentiful these days than before in spite of } \\
\text { recent waste disposal into water source and oil spillages } \\
\text { and the use of chemicals, explosives as fishing } \\
\text { mechanism }\end{array}$ & $\begin{array}{l}57 \\
(9.8)\end{array}$ & $(5.1)$ & 495 \\
$(84.9)$ & 582 \\
$(99.9)$
\end{tabular}

A whopping $84.9 \%$ of the respondents believed that there is a reduction in the amount of fish brought home from fishing activities as against $9.8 \%$ and $5.1 \%$ who disagreed on the reduction and were not sure of the reduction respectively. The $9.8 \%$ and $5.1 \%$ who respectively, disagreed and were not sure, may not depend on fishing for livelihood hence their uncertainty. The majority affirmative response that underscores a reduction in the amount of fish fetched home from fishing activities, did further confirm that apart from oil related water pollution, the recent use of chemicals and explosives as part of fishing strategies is also detrimental to the water bodies. This response agrees with Powell (1988) who observed that the explosion of dynamites in water bodies produces narcotic effects and, readily, outright mortality of fish and other fauna. Mortal damages arising from dynamite shooting is non-selective, killing all stages of fishes and other edible and non-edible living materials within the system. Furthermore, in a study carried on fish and fisheries in Ikata, Okoma and Oshika all of Rivers State West, Powell reports a reduction in fish abundance, total loss of species lacking accessory air-breathing organs and major loss of species without any obvious physiological pattern. Other scholars like Hart, et al. (2007), in their Study on Water quality, species composition and abundance of phytoplankton (like algae) indicated that the condition of Ejamah-Ebubu Swampland (located in Rivers State East) polluted in 1970 had not improved significantly. Regarding the effect of chemicals on water bodies, Owabukeruyele (2000) argues that the compounds from the numerous petroleum wastes contain organic chemicals such as phenol cyanide, sulpheide-suspended solids, chromium and biological oxygen.

Complimentarily, Isiche and Stanford (1976) observe that these chemicals leave destructive effects on both land and water. The above submissions could give a clue to why the amount of fish harvested from the river is reduced due to the recent trend of using explosives, chemicals (by residents) and petroleum waste (by oil companies). In essence, these hazardous activities had brought to fulfillment Hosea's submission that - "the fish of the sea are taken away" (Ho 4:3) - that is, the fish of the sea have been reduced and some have migrated while others have gone into extinction due to the un-conducive environment necessitated by the use of chemicals and explosives as fishing mechanism. With the forgoing facts that even Rivers State residents contribute to environmental degradation in various forms.

Table 4: Test on Respondents' affirmation that neglecting set rules can be detrimental to life patterns

\begin{tabular}{|l|l|l|l|l|l|}
\hline & \multicolumn{1}{|c|}{ ITEMS } & $\begin{array}{l}\text { Agree } \\
(\%)\end{array}$ & $\begin{array}{l}\text { Undecided } \\
(\%)\end{array}$ & $\begin{array}{l}\text { Disagree } \\
(\%)\end{array}$ & Total \\
\hline 1 & $\begin{array}{l}\text { Neglecting 'trivial' but life supporting principles can } \\
\text { affect our environment negatively }\end{array}$ & $\begin{array}{l}448 \\
(76.8)\end{array}$ & $\begin{array}{l}56 \\
(9.6)\end{array}$ & $\begin{array}{l}79 \\
(13.6)\end{array}$ & $\begin{array}{l}583 \\
(100)\end{array}$ \\
\hline
\end{tabular}

Looking at the above test item, we see that $76.8 \%$ of the respondents agreed that neglecting trivial but life supporting principles could affect their environment negatively. This majority response on Item 5 supports Feinberg's (1984) view that severe environmental damage is often the result of the accumulation of individually negligible effects. In other words, when people neglect certain life-giving principles, no matter the degree, its effects tend to accumulate and thus result in environmental damage.

Therefore, by inference, the people's view for remediation is simply "follow set rules or life supporting 
principles and our environmental condition will improve." Moreso, the prevalence of the abrogation of law and ethical principles in a given society results in the increase in environmental damage thus affirming Hayes (2002) position that the theme of reversal of creation is tied within Hosea 4:1-3 as a whole to the abrogation of law and ethical principles at least in Israel and by extension in Rivers State.

\section{The Plight of Fish Famers in Coastal Rivers State}

Fish reduction has some effect on family livelihood in the coastal areas of Rivers State. It is a source of great concern because of the threat to the livelihood of the people. In this paper, we argued that the main economic stay and livelihood of the Rivers people in the Niger Delta region of Nigeria especially, those in the coastal region of the State, is fishing. Fish provides protein for families in the coastal areas of Rivers State and economic wealth for merchants in fish farming. This vital industry is being destroyed by pollutants used in killing fishes in the sea. Such dangerous chemicals like gammalin20 and some other substances are dangerous to the ecosystem. The use of the dangerous chemicals is not only hazardous to the fishes in the sea, but to humans as well. By eating poisoned fish, Families are afflicted with toxins that are detrimental to health and wellbeing. The chemicals, used in killing fishes, also have the potentials to attack and damage vital organs of the body thus leading to organ failure, deformities, and death. A pregnant woman that takes poisoned fish faces the likelihood of the unborn child suffering one form of congenital abnormalities or the other. Poisoned river water and creeks also become very unsafe for drinking and for other domestic uses (Powell, 1987). Environmental degradation constitutes health hazards and avoidable sicknesses for families. Water borne diseases account for the death of so many people in Rivers State (Isiche and Stanford, 1976)). Some of these water-borne diseases are: Typhoid, Cholera, and Paratyphoid fever, Dsysentry, Jaundice, and Amoebiasis. Others are skin diseases, diarrhea, gastric ulcers and respiratory illnesses. Families who ingest contaminated fishes also suffer from indigestion, and common cold which may be a symptom of other forms of diseases. All these impact on the livelihood of families that are already traumatized by the economic situation in Rivers State resulting from fish migration (Joshua, 2015).

\section{Conclusion}

When certain life-giving principles which naturally exist and is made known to all are neglected as Aquinas' paradigmatic theory of Natural Law (Aquinas, 1993) stipulates, no matter the degree, its effects tend to accumulate and thus result in environmental damage. Therefore, by inference economic balance in Rivers State coastal region could be realized if natural laws regarding horizontal (with man and nature) relationships are observed and not ignored. But when ignored, total ruin or destruction remains inevitable.

Nevertheless, unethical conduct which accounts for ecological crisis in water as evident in the book of Hosea and selected communities in Rivers State, resulted from the violation of ethics of environmental stewardship which stresses that the ecological problems, so evident today, such as water pollution, and land degradation are not only environmental but also moral problems. Hence, environmental degradation in selected communities in Rivers State is a reflection of a disconnection between the people's religious belief and their behaviours. This indeed validates Habel's Ecological Hermeneutics (2008) which stresses that human deeds have ecological consequences which apparently affects other aspects of human live including economic life as well. The overwhelming $84.9 \%$ of the respondents who believed that there was a reduction in the amount of fish brought home from fishing activities due to recent use of chemicals and explosives as part of fishing strategies reveals the adverse effect of unethical deeds on the aquatic zone in the region under study. This is further evident as residents from fresh water zone applied gammalin20 while those of saline water zone used dynamite as fishing techniques. Such conduct resulted in non-selective mortal damage, which left water sources stinking after two days and thus, was detrimental to the economic life of families that depended on fishing for livelihood. Giving the forgoing, therefore, the role of residents and the government remains imperative for the environmental remediation in Rivers State as this will ameliorate the economic downturn of fish farmers. There should be valuation of modalities for the enforcements of life-supporting principles, as negligence on the part of government, and contraventions on the part of the Rivers State residents could cause more harm to the economic life of residents within the coastal regions of Rivers State, Nigeria.

\section{References}

Aquinas, T (1993). Commentary on Aristotle's Nicomachean Ethics. Trans. C. I. Litzinger. South Bend, Ind.: Dumb Ox Books. 16. http://plato.stanford.edu/entries/natural-law-ethics/\#KeyFeaNatLawThe (Accessed 25 ${ }^{\text {th }}$ October, 2012).

Berry, S (2005), A Christian Approach to the Environment, $37 \mathrm{ff}$

Bullard, R D (nd.) "Environmental Justice for All" from the World Wide Web: http://nationalhumanitiescenter.org/tserve/nattrans/ntuseland/essays/envjust.htm, (Accessed June 17, 2011).

Davis, WT. Jr., (1974) “A Method For Social: An inquiry into the usefulness of Reinhold Neibuhr's Ethical Model for Social Justice In developing Nation,” in ORITA: Journal of Religious Studies Ibadan, June 1, 22-44. 
Day, AE (n.d). Fish, in ISBE. 3442.

DeWitt, CB. The Religious Foundations of Ecology. The Mother Earth Handbook, Scherff, Judith S., Ed. New York: Continuum. 1991: 253.

Easton's Bible Dictionary (n.d) 'Fish,' 1343, 2711.

Feinberg, J (1984).The Moral Limits of the Criminal Law: Harm to Others. Oxford: Oxford University Press. $1: 225-232$.

Gonzalez, P and Caldelon, A (2008). Methods of Research and Thesis Writing, Manila: National Book Store.

Habel, NC and Peter T, (Eds.) (2008) Exploring Ecological Hermeneutics. Atlanta: Society of Biblical Literature, 2008: xiv -183. http://www.brill.com/exploring-ecological-hermeneutics (Accessed 12.06.2013).

Hart, AI, Amah, E and Zabbey, N (2007) Biocenosis of Planktonic Flora in a 36 years Old Crude Pollution freshwater pond in the Niger Delta, Nigeria. African Journal of Zoology and Environment Biology, 9: 63 69.

Hayes, KM (2002). "The Earth Mourns: Prophetic Metaphor and Oral Aesthetic" SBL Academia Biblica 8, Atlanta: Society of Biblical Literature, 60. See also, the website below:http://books.google.com.ng/books/p/8252592953561564?id=ldfw7nYUe7wC\&pg=PA128\&dq=Hay es, + Katherine + M. + The + Earth + Mourns\&cd $=1 \&$ redir_esc $=y \# v=$ onepage\&q $=$ Hayes $\% 2 \mathrm{C} \% 20$ Katherine $\% 20$ M.\%20The\%20Earth\%20Mourns\&f=false (Accessed $30^{\text {th }}$ December, 2012).

Isiche, AO and Stanford, WW (1976). The Effect of Wastes Gas Flares on Surrounding Vegetation of Southeastern Nigeria" in Journal of Applied Ecology,13: 177-187.

Joshua, N H and Nazrul, IM, (2015). Water Pollution and its Impact on the Health. Journal of Environment and Human, 2/1:40-41

Lernau, H and Lernau, O (1992) "Fish Remains", in A. de Groot and D. T. Ariel, eds., City of David Excavations Final Report III. Jerusalem: Institute of Archaeology, Hebrew University. 131-148.

Lisska, A (1996). Aquinas's Theory of Natural Law: An Analytic Reconstruction. Oxford: Oxford University Press.

Mays, JL, (1969). Hosea: A Commentary. Philadelphia: The Westminster Press, p. 64-65.

Murphy, M (2011) "The Natural Law Tradition in Ethics", in Edward N. Zalta (ed.), The StanfordEncyclopedia of Philosophy (winter Edition),http://plato.stanford.edu/archives/win2011/entries/natural-law-ethics/ (Accessed $25^{\text {th }}$ October, 2012).

National Bureau of Statistics, (NBS) (2007). Annual Abstract of Statistics. Produced under the Auspices of Federal Government Economics Reform \& Governance Project, (ERGP) Federal Republic of Nigeria. p. 39.

Nwaomah SM. (2013). "Eco-Justice and the Niger Delta Environmental Challenges: Reflections on Matthew 7.12" Philosophy Study, Vol. 3. 4. Pp. 291-299.

Owabukeruyele, SW (2000). "Hydrocarbon Exploitation, Environmental Degradation and Poverty in the Niger Delta of Nigeria" a paper presented the Lund University LUMES Program, Lund Sweden in Retrieved from the http://www.waado.org/Environment/PetrolPolution/EnvEconomics.htm (Accessed 10/10/2012).

Patch, James A. Fish. in ISBE 3442

Powell, CB (1988). Effects of Freshwater oil spillages on fish and fisheries. In the Petroleum Industry and the Nigerian Environment, Proceedings of 1987 international seminar

Sakenfeld, KD, (1978). The Meaning of Hesed in the Hebrew Bible. Missoula, MT: Scholars Press.

Terry, MS. (1976). Biblical Hermeneutics NY: Philips and Hunt; reprint, Grand Rapids: Zondervan. 231.

Thomas N (2006), Everyday Living: Bible Life and Times. Nashville, Tennessee: Thomas Nelson, Inc., Publishers. 260-261

Watts, M, (2007), 'The Rule of Oil: Petro-Politics and The Anatomy of an Insurgency', a paper delivered to the Oil and Politics Conference, Goldsmiths College, University of London, May 10-1 $1^{\text {th }}, 15$, www.goldsmiths.ac.uk/csisp/papers/Watts_petropolitics_insurgency.pdf (accessed 10/10/2012).

Witenberg G (2009), "Knowledge of God: the Relevance of Hosea 4:1-3 for a Theological Response to Climate Change" in Old Testament Essay, a Journal of Old Testament Society in South Africa. 22/2. 504 